\begin{tabular}{|l|l|l|}
\hline \multicolumn{2}{|c|}{ PublisherInfo } \\
\hline \hline PublisherName & $:$ & BioMed Central \\
\hline \hline PublisherLocation & $:$ & London \\
\hline \hline PublisherImprintName & $:$ & BioMed Central \\
\hline \hline
\end{tabular}

\title{
Renal and respiratory failure in Scottish ICUs
}

\begin{tabular}{|l|l|l||}
\hline \multicolumn{2}{|c||}{ ArticleInfo } \\
\hline \hline ArticleID & $:$ & 4301 \\
\hline \hline ArticleDOI & $:$ & $10.1186 /$ ccf-2001-73253 \\
\hline \hline ArticleCitationID & $:$ & 73253 \\
\hline \hline ArticleSequenceNumber & $:$ & 12 \\
\hline \hline ArticleCategory & $:$ & Paper Report \\
\hline \hline ArticleFirstPage & $:$ & 1 \\
\hline \hline ArticleLastPage & $:$ & 3 \\
\hline \hline & & RegistrationDate : 2001-12-4 \\
ArticleHistory & $:$ & Received \\
\hline ArticleCopyright & $:$ 2001-3-28 \\
\hline \hline ArticleGrants & $:$ & OnlineDate \\
\hline \hline ArticleContext & $:$ & 1305455 \\
\hline \hline
\end{tabular}




\section{Keywords}

Acute renal failure, haemofiltration, mechanical ventilation, respiratory failure

\section{Context}

The mortality rate for respiratory and renal failure in the ICU varies between $60 \%$ and $90 \%$ and has not improved despite renal supportive therapies. This study reviewed the outcome for 16 Scottish ICUs over a 2-year period, and determined the incidence of subsequent end-stage renal failure (ESRF) in survivors of acute renal failure.

\section{Significant findings}

Mortality was $64.2 \%(392 / 612)$ for patients with respiratory and renal failure. Non-survivors were significantly older ( 60 versus 53 years, $P<0.002$ ). Of the survivors, $33 \%$ of those with pre-existing renal failure developed ESRF; $1.6 \%$ of patients without pre-existing renal failure developed ESRF.

\section{Comments}

This study supports previous work looking at outcomes in patients with respiratory and renal failure in the ICU. The authors claim this is the largest number of patients studied in one trial to date, and that is the only trial to cover an entire country. The study cannot confidently unravel the reasons for the lack of improvement in outcome over time, but postulates that it reflects an ageing population with more comorbidity who may not have survived previously. It drives the point home that renal failure remains very bad news in the ICU and, for the present, progress can really only be made in preventing its occurrence. This may require critical care support to expand outside the ICU to identify and commence early interventions in the at-risk patient. It is, however, reassuring that those without pre-existing renal failure who survive the ICU, do not go on to develop ESRF, implying that renal supportive therapies are not futile. 


\section{Methods}

Retrospective analysis of a database over a 2-year period (1995-1997), identification of renal and respiratory failure from TISS scores, and case-note validation to identify patients with pre-existing renal failure.

\section{Additional information}

\section{References}

1. Noble JS, MacKirdy FN, Donaldson SI, Howie JC: Renal and respiratory failure in Scottish ICUs. Anaesthesia. 2001, 56: 124-129. 